Témoigner Témoigner. Entre histoire et mémoire

Getuigen Revue pluridisciplinaire de la Fondation Auschwitz

Violences radicales en scène

\title{
Lucy Bond \& Jessica Rapson. The Transcultural Turn: Interrogating Memory Between and Beyond Borders
}

Berlin \& Boston: de Gruyter, 2014

\section{Sara Jones}

\section{(2) OpenEdition}

\section{Journals}

Electronic version

URL: https://journals.openedition.org/temoigner/3749

DOI: $10.4000 /$ temoigner.3749

ISSN: 2506-6390

Publisher:

Éditions du Centre d'études et de documentation Mémoire d'Auschwitz, Éditions Kimé

Printed version

Date of publication: 1 October 2015

Number of pages: 167-169

ISSN: 2037-4183

\section{Electronic reference}

Sara Jones, "Lucy Bond \& Jessica Rapson. The Transcultural Turn: Interrogating Memory Between and Beyond Borders", Témoigner. Entre histoire et mémoire [Online], 121 | 2015, Online since 01 October 2016, connection on 04 February 2022. URL: http://journals.openedition.org/temoigner/3749 ; DOI: https:// doi.org/10.4000/temoigner.3749

This text was automatically generated on 4 February 2022.

Tous droits réservés 


\section{Lucy Bond \& Jessica Rapson. The Transcultural Turn: Interrogating Memory Between and Beyond Borders}

Berlin \& Boston: de Gruyter, 2014

Sara Jones

\section{REFERENCES}

Lucy Bond \& Jessica Rapson. The Transcultural Turn: Interrogating Memory Between and Beyond Borders, Berlin \& Boston: de Gruyter, 2014, 275 p.

1 The Transcultural Turn makes a significant contribution to a growing body of literature that seeks to examine the formation of memory cultures between and beyond national borders.Read together, the thirteen essays that make up this collection build up a picture of a transnational framework in which representations of the past intersect, overlap and conflict in myriad ways. This impressive collection has the potential to have a substantial impact on an emerging field of memory studies that focuses on the ways in which the local, national and global represent distinct, but highly interconnected arenas for individual and collective remembering.

2 Perhaps of most significance for the general memory studies scholar is Bond and Rapson's introduction to the volume. Here, the authors present a well thought-out definition of "transcultural memory", which, while not restrictive, frames the subsequent essays and will be indispensable for all those working in this growing field. They argue that the term encapsulates the porous and interrelated nature of contemporary memory cultures, the transfer of "commemorative tropes and techniques" (19) between different national and ethnic contexts, and the "essentially dialogic relation" (Ibid.) of memories to one another. In these ways, memories travel both within a particular collective, as well as between different groups - a process that pushes us to consider memory outside of "political, ethnic, linguistic or religious 
borders as containers for our understanding of the past" (Ibid.). The volume as a whole aims to elaborate and interrogate this concept of transcultural memory from diverse perspectives and in diverse media.

The remainder of the book is divided into three sections: "theorizing transcultural memory"; "problematizing transcultural memory"; and "the possibilities of transcultural memory". In the first contribution, and in dialogue with one another, Dirk Moses and Michael Rothberg outline their own vision of the transcultural and the potential risks and possibilities that remembering across borders might present. Moses argues that even memories of suffering that claim to be unique are always "implicitly comparative, that is, transcultural" (30). Nonetheless, he makes the important point that "transcultural" does not necessarily mean "cosmopolitan", rather comparative memories can all too quickly become competitive ones. Rothberg similarly sees the concept of the transcultural as essential for understanding the processes of memory, as it draws attention to interaction between the different levels of remembering (local, national, global), as well as the "fuzzy edges of group belonging" (32). Nonetheless, for these interactions to be productive in terms of an ethics of memory, comparison must be based on "differentiated solidarity" (33), rather than equation and competition. While this is not the only place that both scholars have advanced these perspectives, their inclusion here is an important reminder that we must ask ourselves to what end and to what effect memories, tropes and methods of working through the past cross (national) borders.

In the subsequent chapter, Peter Carrier and Kobi Kabalek interrogate the concepts of "memory", "culture", "cultural memory" and "memory culture" in order to better understand the foundation of "transcultural memory". The authors argue that transcultural memory studies would benefit from drawing on some of the methods and concepts used in heritage studies, political science, history and sociology. A number of the distinctions made here between different approaches seem rather rigid and more could have been done to acknowledge interdisciplinary work being done in this field. Nonetheless, Carrier and Kabalek are right to point out that memory studies scholars in general need to be more explicit in their definition and use of the term "memory" in order to allow dialogue between academics working in different contexts. Bond's analysis of transculturality in the subsequent chapter focuses specifically on the commemoration of $9 / 11$ and the narrative forms attached to this catastrophic event. Her emphasis on narrative and genre provides an interesting methodological approach that might apply to other contexts.

The chapters grouped under the heading "problematizing transcultural memory "build on these theoretical reflections, but take individual case studies to explore the potential difficulties of establishing a transcultural memory. The first three essays locate their analysis within the framework of European memory and thereby contribute to a burgeoning body of work that seeks to understand if and how the European nations can (and indeed if they should) foster a common identity based on shared pasts. Lars Breuer's fascinating study of the national, transnational and European in German and Polish "vernacular memory" demonstrates that national and European memory are not in competition, rather they are "mutually constitutive domains" (83). National self-understandings are challenged by European memory discourses leading to both reassertion and re-negotiation of those self-understandings. Taking a supranational perspective as her starting point, Aline Sierp interrogates the 
concept of the Second World War as the founding myth of the European Union. She identifies a resurgence of references to this notion in the post-1989 period and a growing emphasis on memory of the Holocaust as the foundation of Europeanization. This has not, according to Sierp, resulted in a reflexive mode of remembrance at the national level, and shared memories of war and dictatorship might continue to do more to divide, rather than unite.

6 The interaction between the national and transnational is also the focus of Andy Pearce's exploration of the development of Holocaust memory in Britain and its relationship to Europeanization and Americanization. Through tracing the history of key media events and public education initiatives relating to memory of the genocide, Pearce demonstrates that this relationship cannot simply be understood as an "importing" of memory cultures from other contexts, rather that Britain both shaped and was shaped by transnational shifts in modes of remembering, which nonetheless remain rooted in the framework of the nation state. In the final chapter in this section, Rapson explores the unusual case of memorialization of the Babi Yar massacre, in which a process of forgetting at the authentic site in Kiev is mirrored by active remembering thousands of miles away in Denver, Colorado. She argues that "multidirectionality" might be deployed productively in Ukraine to allow the coexistence of memories of the Holodomor and of the Holocaust, but that the site has hitherto been dominated by political concerns. On the other hand, comparison of the Holocaust with $9 / 11$ at the site in Denver - though based on a desire to promote ethical engagement beyond national borders - risks erasing essential differences between these catastrophic events.

7 The five chapters in the third section of the volume draw on particular case studies to show the potential of the transcultural to promote just such an ethical perspective. Wendy Koenig considers the importance of acoustic design in Holocaust museums in terms of promoting visitor engagement with pasts that are not their own and transmitting memories across borders. Terry Tomsky explores how Dubravka Ugresićs novel The Museum of Unconditional Surrender (1996) draws on the representation of "other" pasts (notably the Holocaust and the Cold War) to construct a Yugoslav collective identity and memory, shattered in the wake of civil war and the break-up of the state. Franziska Meyer also considers the transcultural potential of a literary work in her discussion of Katharina Hacker's The Have-Nots (2006). Through a close reading of Hacker's text, in dialogue with Walter Benjamin's Berlin Childhood and On the Concept of History, Meyer demonstrates how an aesthetic of attentiveness to the pain of others can challenge hegemonic narratives relating to the past - in this case, experiences, versions and memories of $9 / 11$ that are presented as universal. Dirk Göttsche provides a comprehensive overview of cross-cultural and, indeed, inherently multidirectional memories in historical novels about Africa, the works of African migrants writing in German and writing by Black Germans since the 1980s. Finally, Marguérite Corporaal analyses the transcultural in memories of the Great Famine, comparing nineteenthcentury works of Irish writers in Ireland, with those by members of the Irish diaspora. She demonstrates the interaction between a "transnational tradition of remembrance shared by the homeland and the American diaspora" and "North American forms of cultural remembrance" (250).

8 Despite the diversity of topics and media addressed, the volume is remarkably coherent. The different chapters speak to each other and to an overarching theoretical 
framework that draws on existing concepts within memory studies, whilst simultaneously developing new understandings of what the "transcultural turn" is and how it might help us understand how the past circulates in the present. Although further contextualization and/or examples are needed in some of the chapters, the essays are generally very well written and accessible. Unusually for a work of this type, the individual case studies each broaden out their analysis to make clear what they might offer to scholars working on similar issues in different contexts. This important volume will thus help those working in the field to hone their sensitivity to the porous nature of what might be described as "memory borders", without losing sight of the ongoing significance of national, ethnic and religious divisions.

\section{AUTHORS}

\section{SARA JONES}

University of Birmingham 